\title{
Korean Forest Database
}

\author{
Tomáš Černý, Miroslav Šrůtek, Petr Petřík, Jong-Suk Song \& Milan Valachovič
}

\begin{abstract}
The Korean Forest Database (GIVD ID AS-00-001), with 2,207 relevés, covers the main gradients and composition of forests (partly non-forest vegetation) from the sealevel to highest peaks (Paektusan, Hallasan) of the Korean peninsula and neighbouring areas (Russia, China). Altogether, 44 principal studies published in Korean journals and monographs in the last 30 years were analysed. The occurrence of natural or semi-natural forest stands was a selection criterion to be included as a record into the database. The relevés were sampled using the standard Zürich-Montpellier methodology, with the Braun-Blanquet semi-quantitative scale. The mean species richness is about 30 species per relevé (moss layer excluded). A relevé area over $100 \mathrm{~m}^{2}$ occurs in $36.5 \%$ of relevés and the size of $400 \mathrm{~m}^{2}$ in $20.6 \%$, respectively. The vertical distribution of the relevés mirrors the land topography, so $39.5 \%$ were recorded below $500 \mathrm{~m}, 34.5 \%$ were recorded in the belt $500-1,000 \mathrm{~m}, 14.9 \%$ in the belt 1,000-1,500 m and $6.1 \%$ of relevés come from the highest stands. The most frequent woody species presented are Quercus mongolica, Lindera obtusiloba, Acer pseudosieboldianum, Rhododendron schlippenbachii, R. mucronulatum, and Pinus densiflora. Among the most frequent herb species occur Carex siderosticta, Disporum smilacinum, Aster scaber, Carex lanceolata, Artemisia keiskeana, and Ainsliaea acerifolia. All relevés are georeferrenced in the WGS84 coordinate system, more or less precise. The study was funded by research grant nr. 206/05/0119 of the Grant Agency of the Czech Republic, and the research grant nr. IAA600050802 of the Academy of Sciences of the Czech Republic. This work was supported as a long-term research development project no. RVO 67985939 and the International Research Cooperation Program (Nr. F01-2009-000-10022-0) funded by the National Research Foundation of Korea.
\end{abstract}

Keywords: Quercus mongolica and Abies koreana forest; phytosociology; South East Asia.

\begin{tabular}{|c|c|}
\hline GIVD Database ID: AS-00-001 & Last update: $2012-05-06$ \\
\hline \multicolumn{2}{|l|}{ Korean Forest Database } \\
\hline \multicolumn{2}{|c|}{$\begin{array}{l}\text { Scope: Relevés of natural forest vegetation, mostly from the Korean peninsula, recorded by the use of Braun-Blanquet scales and Zürich- } \\
\text { Montpellier methodology and published in local ecological journals and monographs by various authors. A minor portion of original relevés of the } \\
\text { same quality is included, being recorded in national parks with well-preserved forests. }\end{array}$} \\
\hline Status: completed and continuing & Period: $1978-2010$ \\
\hline \multicolumn{2}{|c|}{$\begin{array}{l}\text { Database manager(s): Tomáš Černý (tomas.cerny@ibot.cas.cz); Miroslav Šrůtek (miroslav@srutek.cz); Petr Petřík (petr.petrik@ibot.cas.cz); } \\
\text { Jong-Suk Song (quersong@yahoo.co.kr); Milan Valachovič (milan.valachovic@savba.sk) }\end{array}$} \\
\hline \multicolumn{2}{|c|}{ Owner: Institute of Botany of the Czech Academy of Sciences } \\
\hline \multicolumn{2}{|c|}{ Web address: $[N A]$} \\
\hline Availability: according to a specific agreement & Online upload: no \\
\hline Database format(s): TURBOVEG & Export format(s): TURBOVEG, Excel, CSV file \\
\hline \multicolumn{2}{|l|}{ Publication: [NA] } \\
\hline Plot type(s): normal plots; nested plots & Plot-size range: $12-900 \mathrm{~m}^{2}$ \\
\hline Non-overlapping plots: 2,007 & Estimate of existing plots: $10,000 \quad$ Completeness: $20 \%$ \\
\hline Total plot observations: 2,207 & Number of sources: 44 \\
\hline \multicolumn{2}{|c|}{ Countries: CN: $2.1 \% ; \mathrm{KP}: 11.8 \%$; KR: $83.7 \%$; RU: $1.4 \%$} \\
\hline \multicolumn{2}{|c|}{ Forest: $97 \%$ - Non-forest: aquatic: $0 \%$; semi-aquatic: $0 \%$; arctic-alpine: $2 \%$; natural: $1 \%$; semi-natural: $0 \%$; anthropogenic: $0 \%$} \\
\hline \multicolumn{2}{|c|}{ Guilds: all vascular plants: 100\%; bryophytes (terricolous or aquatic): 11\%; non-terricolous taxa (epiphytic, saxicolous, lignicolous): $5 \%$} \\
\hline \multicolumn{2}{|c|}{$\begin{array}{l}\text { Environmental data: altitude: } 95 \% \text {; slope aspect: } 85 \% \text {; slope inclination: } 92 \% \text {; surface cover other than plants (open soil, litter, bare rock etc.): } \\
10 \%\end{array}$} \\
\hline \multicolumn{2}{|l|}{ Performance measure(s): cover: $100 \%$} \\
\hline \multicolumn{2}{|c|}{$\begin{array}{l}\text { Geographic localisation: GPS coordinates (precision } 25 \mathrm{~m} \text { or less): } 13 \% \text {; small grid (not coarser than } 10 \mathrm{~km} \text { ): } 48 \% \text {; political units or only on a } \\
\text { coarser scale }(>10 \mathrm{~km}): 39 \%\end{array}$} \\
\hline \multicolumn{2}{|c|}{ Sampling periods: $1970-1979: 2.0 \% ; 1980-1989: 40.0 \% ; 1990-1999: 42.0 \% ; 2000-2009: 13.0 \% ; 2010-2019: 3.0 \%$} \\
\hline Information as of 2012-07-12; fur & Irther details and future updates available from http://www.givd.info/ID/AS-00-001 \\
\hline
\end{tabular}

Tomáš Černý* (tomas.cerny@ibot.cas.cz), Petr Petř́k (petr.petrik@ibot.cas.cz)

Department of Geobotany, Institute of Botany of the Czech Academy of Sciences, Zámek 1, 25243 Pruhonice, CZECH REPUBLIC

Miroslav Šrůtek (miroslav@srutek.cz)

Department of Botany, Faculty of Science, University of South Bohemia, CZ-370 05 Ceske Budejovice, CZECH REPUBLIC 
Jong-Suk Song (quersong@yahoo.co.kr)

Department of Biological Science, College of Natural Sciences, Andong National University, Gyeongbuk, 760-749 Andong, KOREA, REPUBLIC

Milan Valachovič (milan.valachovic@savba.sk)

Department of Geobotany, Institute of Botany of the Slovak Academ, Dubravska cesta 9, 84523 Bratislava, SLOVAKIA

*Corresponding author 